The Geography of the Upper Waitaki Basin, New Zealand: Discussion

Author(s): Dr. Strahan, P. F. Kendall, A. M. Finlayson, Mr. Allorge, A. E. Kitson and E. O. Thiele

Source: The Geographical Journal, Vol. 36, No. 5 (Nov., 1910), pp. 551-553

Published by: geographicalj

Stable URL: http://www.jstor.org/stable/1777342

Accessed: 21-06-2016 10:18 UTC

Your use of the JSTOR archive indicates your acceptance of the Terms \& Conditions of Use, available at

http://about.jstor.org/terms

JSTOR is a not-for-profit service that helps scholars, researchers, and students discover, use, and build upon a wide range of content in a trusted digital archive. We use information technology and tools to increase productivity and facilitate new forms of scholarship. For more information about JSTOR, please contact support@jstor.org.

The Royal Geographical Society (with the Institute of British Geographers), Wiley are collaborating with JSTOR to digitize, preserve and extend access to The Geographical Journal 
The Waitaki basin is due to pre-glacial erosion, faulting, with probably some warping, modified by glacial action. The large existing lake of Tekapo, Pukaki, and Ohau are simple barrier lakes.

Dr. Strahan: Our thanks are due to these authors for an interesting account of a region, unfortunately distant from us, which evidently presents both geological and geographical problems of great importance. Our time is too limited for a full discussion on so large a subject, but we shall be glad to hear any remarks.

Prof. P. F. Kendall : It is an exceedingly interesting paper, and it is very satisfactory to have a really detailed description from the geographical and geological point of view of this very interesting region. We in the northern himisphere have long desired to know what the evidence was for a Plesstocene glacial period in the southern bemisphere, and the authors have furrished us witb some of the data we required. I wish that, perhaps on some future occasion, they would add a little information as to the nature of the evidence for the advance of the Pleistocene glaciation down to the Ben More range. They have given us proofs, ample and convincing, of its extension down to the termination of these lakes, but what is the evidence for its further extension down to the brink of the plains? That would be very valuable, because I think it would help us to arrive at some conclusion as to whether there was a glacial period in the southern hemisphere, or whether there was merely such an extension of the glaciers as could be explained by some minor readjustment of the meteorological conditions.

Mr. A. M. Finlayson: I am very glad to have an opportunity to listen to this paper, because, though I am not familiar with that particular basin, I know some of the country to the north and also on the west coast, as well as the Lake district to which Mr. Kitson has referred. Of course the paper opens up the vexed question of the influence of former earth-movement in causing some of these gergraphical features, and it appears, from the trend of views at present, that New Zealand is going to be a keen debating-ground for that controversy. In the early days the only move in this direction was Hochstetter's highly speculative hypothesis of radial faults, for which there was very little evidence. More recently Prof. Gregury advocated the existence of great earth-fractures as the cause of many of the physiographical features. His views are very suggestive, but there is little evidence in support of any of the assumed fracture-lines. Since then faults have been called up to account for the formation of Lake Wakatipu basin, and also for sume of the river gorges on the west coast. I have been in both these districts, and it seems to me that the evidence so far adduced is insufficient. For that reason this paper is very welcome, beciuse it is a description of a confined area, and it is only by such detailed work that any conclusions can be drawn in either direction. I have little doubt that earth-fractures must have played a very important part in a uumber of the districts of New Zealand, but what we want is more definite evidence, and this can only be got from work on detailed areas. In regard to the ice question in itself the author's work is very valuable, because quite lately a controversy has arisen over the glaciation of the South Island. Prof. Park has introduced an icesheet hypothesis, and this has been vigorously opposed by Prof. Marshall. The discussion, when it is published, will do a great deal towards clearing up controversial points, and, coming at this juncture, the authors' paper will be a valuable addition to the evidence already possessed of the nature and extent of glaciation in New Zealand.

Mr. Allorge : I should like to know if there is evidence of several glacial 
prriods in New Zealand? We know that a German investigator, Prof. G. Steinmann, has been recently engaged in studying the glaciation of the Andes in South America, and I think his conclusion is that there are several glacial periods, and he goes so far as to say that they are probably synchronous with the glaciations of the northern hemisphere, simply by following the glacial marks along the Andes and through Central America into the Rocky mountains. I should like to know if in other parts of the southern hemisphere there are also indications of several glaciations?

Mr. KIrsoN: I thank all present for the kind way in which they have received our paper. In reply to Prof. Kendall, I may say that our observations did not extend to the Waitaki gorge, and so we cannot, on the field evidence, express an opinion as to whether or not the old Tasman glacier reached that locality. Haast, however, has described morainal deposits on the highlands between the Waitangi plains and the coastal plains to the south-east, and he held the view that the whole of this country to the alpine ridge was covered by an ice-sheet. McKay describes o!d moraines in the Waitaki valley, between the junction of the Ahuriri and the Hakataramea with the Waitaki. $\ddot{A}$ general consideration of the evidence in the basin of the Waitaki inclines me to the opinion that the old Tasmanian glacier may at one time have reached the Waitangi gorge. As regards the causes that operated in the formation of the New Zealand sounds, we have in this paper not discussed the corrosive power of glaciers, for the glacier features in the area dealt with do not call for any special consideration of it. I do not doubt that under certain conditions glaciers have great corrosive as well as erosive power, but I cannot accept the intense corrosive action ascribed by some writers to glaciers in the cutting of the steep-sided valleys, several thousand feet deep, through hard crystalline and metamorphic rocks, such as are found in the fiord region of the province of Southland. It seems to me more probable that intense river action along faultlines is in the main accountable for these deep valleys. No doubt glaciers subsequently played an important part by erosion, and to a less degree by corrosion, in modifying these valleys. Their over-deepening may probably be explained by differential erosion.

Further, these main valleys generally conform to the strike of the crystalline rocks, while the tributary valleys cross the strike at varying angles. The cutting of the main valleys, therefore, must have proceeded at a much more rapid rate than that of their tributaries.

Prof. Kendall remarks that the proportion of ice to rock material at the end of a glacier is the same as that in any given transverse section along its course in the main valley, and that, therefore, at the melting of such a glacier there should be only this amount of material left as terminal moraine. This, however, need not necessarily be the case. If the melting of a glacier proceed at a more rapid rate than that at which the issuing streams can redistribute the morainal material, there will be a mass of such material left behind, and it will continue to increase rapidly, e.g. the case of the present Mueller glacier. As regards the old Tasman glacier, it is advanced that there was a very rapid melting, therefore a vast mass of moraines would escape destruction by the redistributing streams.

In reply to Mr. Allorge: No attempt appears to have been made to synchronize New Zealand glaciation with that of America. In New Zealand only one period of glaciation has apparently been recognized, viz. that from the Cainozoic or Pleistocene continuously to the present time. In Australia, however, glacial conditions are known in the Cambrian, Permo-Carboniferous, and Pleistocene, while in the Jurassic lacustrine beds I have found evidence pointing strongly to glacial conditions existing in the land bordering the Jurassic lakes. In Tasmania, Permo- 
Carboniferous and Pleistocene glaciation has been proved. There is not sufficient evidence to show whether or not the Australian, Tasmanian, and New Zealand Pleistocene glaciation is due solely to local meteorological conditions.

In reply to Mr. Finlayson: I am pleased to know that the question of glaciation in the south island of New Zealand is receiving the special attention of distinguished New Zealand geologists, and I shall look forward with interest to the publication of the results of their work.

Mr. Thiele : Mr. Kitson has fully expressed my views, and I may just emphasize what he has said with regard to glacial action. I cannot accept the extreme glacial corrosion that has been brought forward by some writers to explain the origin of the fjord region. Prof. Kendall referred to the relative quantity of rock carried by a glacier in any given cross-section. From what I have seen of the New Zealand glaciers, there was undoubtedly a considerably greater amount of rock material on the lower portions than in the middle section. There is a large amount of concentration of rock going on in the last few miles of the lower portion on account of the melting away of the ice, and that seemed to be a particular feature of the present glaciers, providing just the conditions for the formation of a lake in a similar way to what happened on the larger scale in the case of the old Tasman glacier.

Dr. Strahan: This paper has presented problems, many of them surpassing interest. It only remains for me to ask you to record a vote of thanks to the authors for their communication.

\section{THE FIRST TRANSANDINE RAILWAY.}

\section{By W. S. BARCLAY.}

AFTER difficulties which have delayed its construction for close upon forty years, the railroad across the Andes uniting Buenos Aires to Valparaiso was opened to traffic on the Centenary of Argentine Independence, May 25, 1910.

\section{"The tumult and the shouting dies,}

The captains and the kings depart."

Inaugural and centenary festivities and speeches are over now, and an important new factor in the world's transport has been made over in perpetuity to public service. It is worth while summarizing the work which has brought about this result, and the new conditions it has brought into being. For communications throughout the world are ever growing closer, and the tightening of any one thread in the gigantic web affects the whole in ways formerly unknown.

\section{Geographical Advantages.}

The Transandine railroad crosses the Andes at the Uspallata pass, in lat. $33^{\circ} \mathrm{S}$. In most of the cross-sections of the Andes from this point northward, a triple cordon, consisting of the coast range, the main Cordillera, and an inland parallel range, have in turn to be surmounted. But the headwaters of the Mendoza river flowing eastward, and those of the 